\title{
Curating collapse: performing maritime cultural heritage in Iceland's museums and tours
}

\author{
Anna S. Antonova ${ }^{1}$ (D) $\cdot$ Alison Rieser ${ }^{2}$ \\ Received: 14 May 2018 / Accepted: 1 November 2018 / Published online: 20 November 2018 \\ (C) The Author(s) 2018
}

\begin{abstract}
Industrial fishing has shaped Iceland for centuries, serving as social mortar, fueling Icelandic independence, and underscoring its geopolitical strategies. With the reorganization and enclosure of fishing in the twentieth century, however, rural coastal communities increasingly turned to tourism as a significant source of revenue. This transitional process is not straightforward, raising complex questions of shifting cultural and social identity for these communities. This paper represents a pilot study of maritime heritage discourses from museums, tours, and attractions in urban Reykjavík and in remote locations in northern Iceland. We examine these different discourses and the local dimensions of social change they perform or communicate through a lens of political ecology and maritime cultural heritage studies.
\end{abstract}

Keywords Fisheries $\cdot$ Tourism $\cdot$ Maritime cultural heritage $\cdot$ Political ecology $\cdot$ Iceland

\section{Introduction}

The rise and fall of fishing as a livelihood has shaped Iceland for centuries. Fishing played an important role in Iceland's settlement and subsequent economic and social development. Along with whaling, seal hunting, and other marine resources, it supplemented Icelanders' diets and their incomes (Magnússon 2010). In the second half of the nineteenth century, with Denmark lifting trade restrictions on Iceland and the establishment of Iceland's national bank (Landsbankinn), the fishing industry provided an opportunity for rapid financial growth (Bogan 2004; Hamilton et al. 2004; Magnússon 2010). Wealth from fishing later helped fuel Iceland's political independence from Denmark in 1944: herring products, in particular, became Iceland's most lucrative export until overfishing and colder ocean conditions resulted in the stock's

Anna S. Antonova

a.s.antonova@leeds.ac.uk

Alison Rieser

rieser@hawaii.edu

1 Marie Skłodowska-Curie Doctoral Research Fellow, University of Leeds, Leeds, UK

2 Department of Geography and Environment, University of Hawaii at Mānoa, Honolulu, HI, USA collapse (Hamilton et al. 2004; Chambers et al. 2017). Nevertheless, fishing continued to underscore Iceland's twentieth-century geopolitics, most famously throughout the Cod Wars, in which Iceland gradually extended its jurisdiction to defend itself from British fishing opportunism (Jóhannesson 2004; Guðmundsson 2006).

However, global pressures from new technologies, overexploitation, and climate change have altered Iceland's marine ecosystems and local communities alike. Practices of enclosure and resource privatization, in particular, have begun restratifying many coastal communities. With the advancement of individual transferrable quotas (ITQs) in Iceland, fishing communities, once the mainstay of Icelandic commodity export, increasingly lost their importance in the national economy, with important consequences of marginalizing rural communities (Benediktsson and Karlsdóttir 2011; Chambers et al. 2017; Kokorsch and Benediktsson 2018). Small-scale fishermen brought legal challenges to the quota system culminating in an appeal to the international human rights committee of the United Nations. Just prior to the economic collapse of 2008, the UN committee found that cultural rights to fishing guaranteed by Icelandic law had not been protected (Einarsson 2011). As a result, in 2009 Iceland introduced strandveiðar, a quota-free system for communities with declining access (Kokorsch et al. 2015; Chambers et al. 2017). Nevertheless, scholars have documented how the introduction and subsequent adjustment of ITQs altered and continue to 
alter the social contract embedded in fishing (Holm et al. 2015), creating rifts within coastal communities (Carothers and Chambers 2012; Chambers and Carothers 2017), and disempowering not only women or non-quota owners (Skaptadóttir 2000; Kokorsch et al. 2015) but also whole communities whose access to collective power has declined (Eythórsson 2000; Eythórsson 2003; Chambers et al. 2017).

Meanwhile, as Iceland has become one of the world's fastest growing tourism economies (UNWTO 2016), the tourist industry has come to represent both an opportunity and an additional pressure for many of these communities. Tourism has indisputably proven beneficial, both on a national level by diversifying Iceland's economy - especially against the backdrop of the financial crisis (Jóhannesson et al. 2010) - and on a local level, particularly with regard to revitalizing areas suffering from industrial decline (Baum 1999). Indeed, as economic and social conditions in some rural communities with small-scale fisheries declined, regional governments looked to tourism to restore their economic health (Benediktsson and Karlsdóttir 2011). But tourism's impact has not been solely positive. The burgeoning tourist population has threatened the quality of the very landscapes the visitors come to see and stressed the local infrastructure supporting their visits (Jóhannesson 2016). Tourism has also accelerated existing economic pressures on local communities. In 2016, for example, as the influx of foreign tourists in Iceland pushed the krona up to the world's second-best-performing currency against the dollar, traditional export industries came to pay a price, with the export of marine products declining by more than 10\% from the previous year's levels (Óladóttir 2016; The Economist 2016). These impacts affect disproportionally small-scale communities dependent on fishing, the same communities most disempowered by the quota system (Eythórsson 2003; Holm et al. 2015).

This article presents an exploratory study of how Icelandic communities implicated in these dynamics understand, address, and perform their own transformations. We present and analyze different discourses representing maritime cultural heritage in several of Iceland's museums, exhibits, and tours-including material representations, where those included elements of curation. We chose to focus exclusively on performative discourses, ones that were deliberately arranged for the tourist eye. We selected these discourses from two main geographic areas (see Fig. 1): first, from a number of exhibits at Reykjavík's Maritime Museum (Víkin), as a highly accessible site representing an overarching national perspective to a majority of Iceland's tourists; and second, from a variety of exhibits, tours, and sites across north-west Iceland, in the Westfjords and Siglufjörður, all in remote areas where communities have been particularly exposed to the dynamics of enclosure, privatization, and social and environmental change (Hamilton et al. 2004; Chambers and Carothers 2017). Taken together, the discourses we collected offer contending local representations of Iceland's landscapes that assert different community experiences of ownership and belonging against the backdrop of changing fisheries management and the rise of tourism. We present an analysis of these themes through the lens of political ecology and maritime cultural heritage studies.

\section{Coastal tourism and maritime cultural heritage: a political ecology lens}

In communities most affected by the historic and economic events we have outlined above, the embrace of tourism economics has served to accelerate, highlight, or exacerbate significant socio-cultural changes. As in other similar cases (Nadel-Klein 2003; Ounanian 2018), Icelandic communities transitioning from more traditional industrial occupations, particularly small-scale fishing, have faced multiple challenges in the process of reconstructing their landscapes as tourism destinations (Jóhannesson and Huijbens 2010). This is consistent with the findings of scholars in political ecology and tourism studies whose works have shown that tourism practices can produce or reflect different power structures of existing sociopolitical, environmental, and economic pressures (Douglas 2014; Sampaio et al. 2014; Mostafanezhad et al. 2016). Significantly, the very act of human conceptualization of the environment, so potent in tourism, can become politicized as a tool in contests over natural resources, property rights, or even means of knowledge (Smith 2003; Peet and Watts 2004; Jóhannesson and Huijbens 2010). Landscapes, as well theorized in the tradition of maritime cultural heritage studies, store lived experiences along with a range of gained meanings, values, and memories (Westerdahl 1992; Tuddenham 2010; Jensen et al. 2011). At the same time, these same environments can present a blank page open to future exploration (Huijbens and Benediktsson 2013). Working landscapes that simultaneously host tourism and hospitality practices inevitably evoke this duality. Hence, natural and cultural heritage in a single landscape can support different, often contending, interpretations of the past and present. These can reinforce local or regional notions of collective meaning, even ownership (Li 1996; Durán et al. 2015) or play to global tourism's promise of transformative personal experiences (Smith 2003; Huijbens and Benediktsson 2013; Sampaio et al. 2014).

In Iceland's resource-dependent maritime communities, these problematic dynamics of shaping a landscape as a destination prove especially poignant given the economic pressures we have outlined above (Benediktsson 2014). The construct of a tourism destination arises from not only physical but also cognitive shaping of a landscape, an interactive process that alternatively builds onto or risks overwriting existing structures of collective knowledge and cultural heritage (Jóhannesson and Huijbens 2010). It is in this interplay that 
Fig. 1 Icelandic places mentioned in the text. Map created by authors

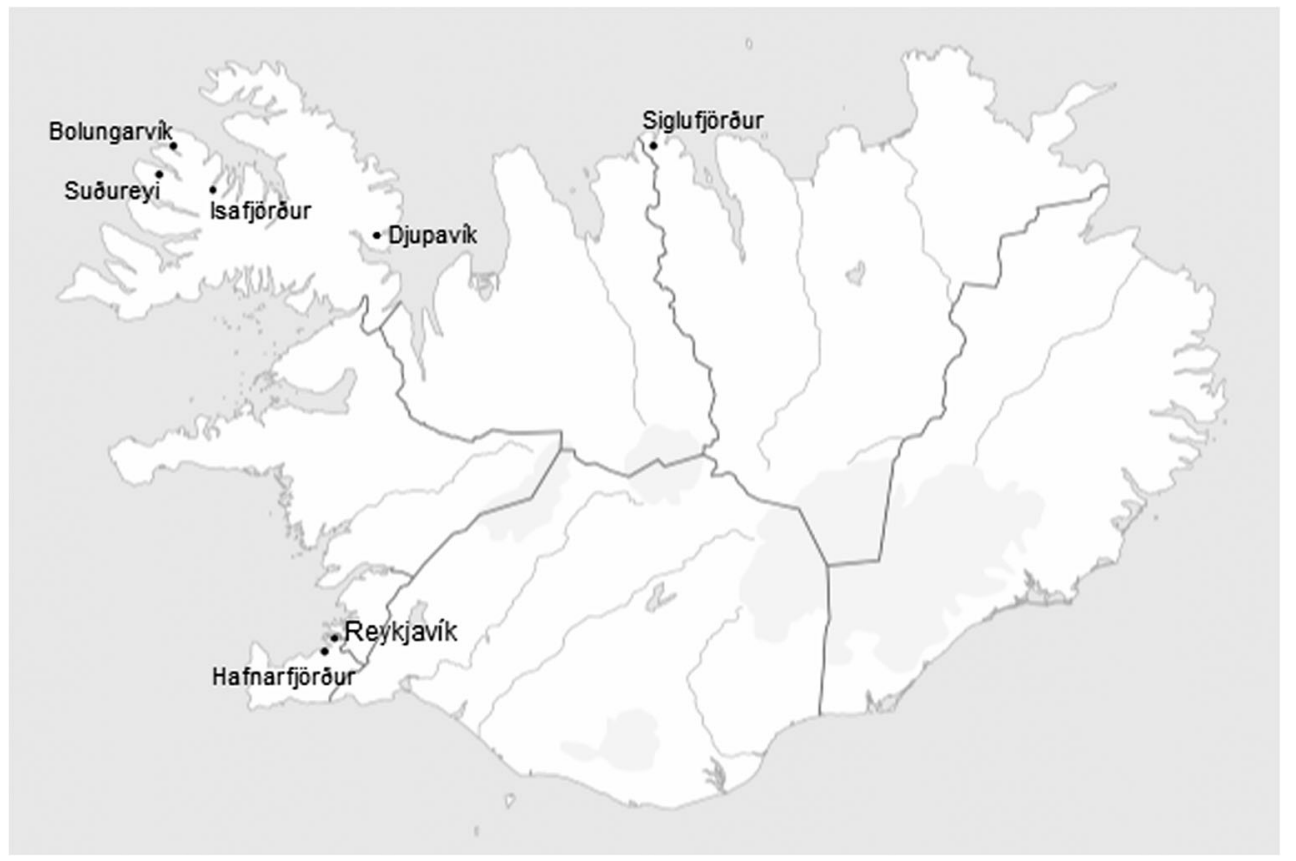

the discursive interaction within communities and between communities and tourists proves significant. The representations of place visible to the tourist gaze in museums, attractions, and tours serve both as a variety of different expressions of community character and as strategies for responding to the economic and social pressures outlined above. Consequently, the discourses associated with the preservation and representation of cultural heritage, including maritime cultural heritage, can tell us a lot about different actors' responses to these pressures.

\section{Methods}

This paper is based on an exploratory pilot study we conducted in July 2016. We followed an inductive approach (Glaser and Strauss 1967) in order to identify what themes would emerge as part of our exploration of different tourist sites representing Iceland's maritime and fishing history. In doing so, we subscribed to Flyvbjerg's view that deep empirical knowledge, particularly acquired through qualitative explorations of a nuanced perspective on reality in a specific case, is central to human learning (Flyvbjerg 2011). We interpreted a range of materials, including texts, films, exhibits, and tours. While similar exploratory methods have been used to chart Iceland's social and cultural history (Magnússon 2010; Oslund 2011), to our knowledge, the performative aspects of its tourism industry remain underexplored as a source for understanding community transitions. We designed our inquiry into these questions as a way to pilot new ways of looking into these processes.
The sites we visited include Ísafjörður's Heritage Museum, the Ósvör fishing outpost museum in Bolungarvík, the seafood trail in Suðureyri, Djúpavík's herring factory and art exhibit, the Herring Era Museum in Siglufjörour, and several permanent and temporary exhibits at the Reykjavík Maritime Museum (Víkin). We identified our sites through preliminary research and network recommendations but we purposefully remained open to new opportunities while in Iceland, particularly in the Westfjords, the most remote fisheries area we visited. Throughout our trip, we aimed to be attentive not only to the written and verbal discourse communicated to tourists but also to the material expressions of each landscape, to the extent that these too were often purposefully constructed, curated, or at least offered for the tourist gaze. This was our first exploratory trip into Iceland's tourist landscapes, and for this trip, we chose to center our interest specifically on those representations that were, at least to some extent, intended for the tourist eye. For that purpose, we focused on discourses already available on display (regardless of the medium) rather than on collecting new narrative material through interview methods. In other words, we exclusively examined deliberately performative discourses, ones that cataloged lived experiences or landscape transformations intentionally for the tourist's interpretation.

In the following sections, we present an account of the observations and themes that emerged from our explorations. Our account is roughly organized by site but in thematic rather than chronological order. In summary, we found different expressions of collective belonging, both local and national, communicated both textually and materially, coexisting with a variety of approaches to "inspiring the visitor" (Huijbens and Benediktsson 2013). All of these discourses present an 
intriguing variety of approaches available to constructing community within and against the changing and evolving maritime landscape.

\section{Discussion}

\section{Fishing, geopolitics, and national identity}

\section{Some like it Cod}

The interplay between fishing and the formation of Icelandic national identity was a prominent narrative inscribed into Iceland's tourist landscapes. This theme manifested especially through narratives of the Cod Wars, which we encountered at several places-indeed, as if to highlight its importance, Cod Wars historian Guðni Th. Jóhannesson had at the time of our visit only just been elected (the previous month) President of Iceland (Gopnik 2016). The theme of the Cod Wars as a constitutive, formative process for Icelandic self-identity was easily evident at the Reykjavík Maritime Museum (Víkin). Not coincidentally, the museum overlooks the retired Coast Guard vessel, Óðinn, famous for cutting the trawlnet warps of the British trawlers sent to contest Iceland's declared exclusive fishing zones. Visitors can tour the Óðinn: they are invited to attempt to lift the trawl warp cutter on its afterdeck, visit the powerful diesel engines below decks, or take photos while wearing the captain's hat. From a political ecology point of view, this materialand-narrative display immediately could be seen to stake a very specific ownership claim over oceanic resources and a national identity associated with it. As Tania Murray Li has argued (Li 1996), representation can play a deliberately strategic role in reinforcing the property claims of communities in conflict. Indeed, in many political and economic contexts at both international and local levels, Li tells us, representations play a vital role, either by deploying new visions or by oversimplifying images (Li 1996). In this case, the Ódinn, complete with the captain's hat, can be seen to play either function. It reinforces the outcome of a serious conflict, resolved in Iceland's favor, which determined the new regime of ocean governance for the twentyfirst century. Simultaneously, however, this representation asserts a sense of collective association. The visitor is invited to celebrate a national identity, and its extension of oceanic power, to which she or he does not belong.

However, while the Óđinn exhibit emits nationalist pride, the Víkin itself shows a concern for presenting a more multifaceted perspective. A temporary exhibit on the Cod Wars, entitled "For Cod's Sake" and designed by museum studies students at the University of Iceland (see Fig. 2), displayed the role these events played in constructing Icelandic nationalism

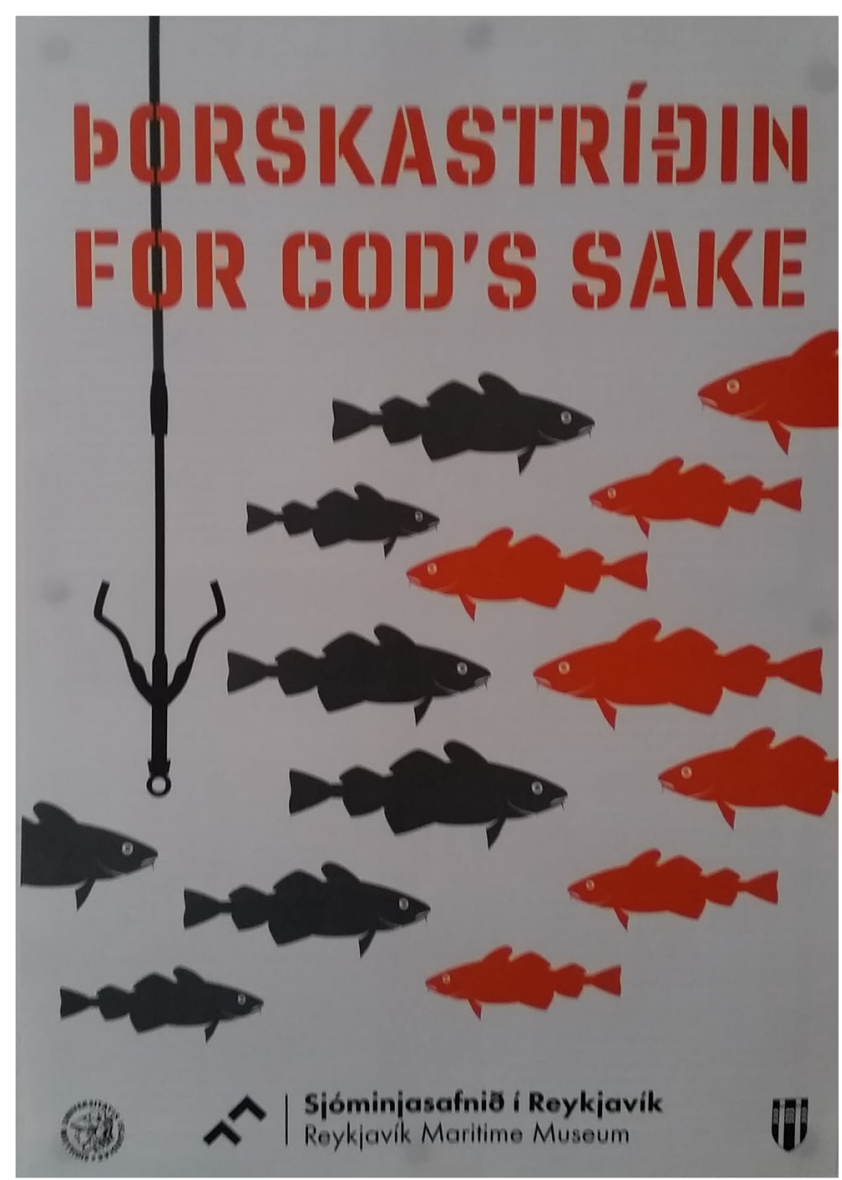

Fig. 2 Exhibit poster with cod fish and trawl warp cutter at Víkin maritime museum, Reykjavík. Photo by authors

not in isolation, but instead in relation to global events. The exhibit offered reflexive interpretations of the role played by fishing in Icelandic economic development and political independence. Plaques capped with the stylized profiles of Coast Guard vessels, including the Ódinn itself, complicated the Cod Wars' history and portrayal as heroism. They discussed the Cod Wars as a symbol in politics and pop culture, as well as a series of events. One such plaque enabled a nuanced understanding by quoting Guðni Th. Jóhannesson:

The Cod Wars are an important part of Icelanders' collective memory. They are said to be an illustrative example of the resilience that the nation can display when it is confronted and evidence of Icelanders' relevance internationally. Some of this is true, but the history is somewhat more complicated when reviewed closely. The unity is exaggerated; little is made of the fact that the Icelanders had to negotiate our victory, and a misunderstanding regarding Icelanders' initiative regarding the laws of the sea is perpetuated. The result is the myth of united heroes, and the real picture fades in the shadows. 
This quote usefully sets Icelandic sense of identity and historical memory against a broader context of environmental, geopolitical, and legal change. In discussing the confrontation with Britain, for example, the exhibit used its space to explain that country's own claims of historic fishing rights and national identity. "For Cod's Sake" featured accounts of the wealth and pride felt by long-distance trawlermen. It highlighted, among other examples, the work of British historian Alec Gill on Hull's Hessle Road trawling community (Gill 2003) and displayed images representing that community's decline in subsequent years. Through such means, the exhibit made a point of commenting on the historic changes that enabled Iceland to win the Cod Wars. Connectivity-across historic events, across scales and localities in an increasingly global world, and across social, economic, and ecological factorswas communicated to the exhibit's visitors visually, as well, through the device of an orange string running its length.

The transition from the Ódinn to the "For Cod's Sake" exhibit could be interpreted, in contrast to the rather simplistic image embodied solely by the Óðinn itself, to represent Iceland's evolving perspective on constructing national identity. Where the Coast Guard vessel narrates heroic military nationalism, the more recent exhibit's complications show cognizance of global complexity. In the exhibit, the accretion of extended jurisdiction and collective memory on Iceland's side existed side by side with the erosion which affected British long-distance trawling communities. This charting of the rise and decline in Hull's Hessle Road community performs an understanding of global connections and interdependence and reflects Anna Tsing's account of "friction," especially its indivisibility from the motion associated with global ecological and economic forces (Tsing 2005). Indeed, through a political ecology lens, the "For Cod's Sake" exhibit emphasizes the interplays in power between not only economies but also ecologies in a global fabric of friction and to the multiplicity of experiences produced by these interactions (Tsing 2005). These themes did not appear in the exhibit by accident. They acknowledge Iceland's own vulnerability to global changes and the significant role played by non-Icelandic forces in shaping the country. The Víkin's narratives, therefore, begin to engage in wider questions of power that transcend the local scale and pay attention instead to the way that Icelandic communities may be embedded in global ecologies and economies. The Víkin's self-awareness in propagating this narrative could be read equally in its other exhibits.

\section{From poverty to abundance}

"From Poverty to Abundance," a poignantly entitled permanent exhibit at the Víkin, describes Iceland's early accumulation of wealth and social permanence due to the livelihoods of fishing and fish preservation. For centuries, Icelandic fisheries were carried out in open rowboats, by women and men who fished with hand lines for demersal species of cod, haddock, wolf fish, and sharks. Under contract to wealthy farmers of the island's interior, fishers were required to leave the farms and fish during the winter months, when dry-air preservation was possible and their labor was not needed on the snow-covered farmlands (Sveinsson 1997). Fishing crews kept their vessels on lava-rocky beaches at outstations along the outer mouths of the fjords. Crew members would launch the rowboats from the beach dragging them over the rocks until they reached waters deep enough to begin rowing. After fish were caught and landed, the captain directed the drying and salting activities, converting the fishes' bodies into commodities that could be stored or traded with distant cities (Pitcher and Lam 2015). While the captain did the salting, after hanging the catch in the drying sheds, crew members prepared their gear and bodies for the next day's hours of rowing and fishing.

The Víkin performs these historic practices and experiences for the visitor. Its exhibit features lifelike recreations of the homes, offices, fish drying yards, and fishing vessels typical of that time, all illustrating vividly the materiality of fishing "taskscapes" (Benediktsson and Waage 2015). Although the visitor can physically enter and observe this realistic display, these experiences are nevertheless arranged as museum components and are not interactive. The display's performativity is highlighted in some of its less obvious elements. For example, the exhibit displays a replica of a fish drying area next to a reproduced illustration of a pre-industrial fishing village, Hafnarfjörður. According to the wall text, this drawing was made by an unnamed illustrator accompanying Joseph Banks during Britain's first official expedition to Iceland in 1772. The text reads, "Boats and storehouses in Hafnarfjörður. [ ... ] These are the first accurate drawings of the Icelandic rowboat" (Víkin 2016). Because these drawings comprised a significant element of official expeditions, they themselves speak to the construction of the landscape as a cultural and even historical entity (Bonehill 2014). Like cartography, these drawings were instruments of land enclosure (Olwig 2005; St. Martin 2009). The inclusion of these drawings suggests to the viewer that the Icelandic landscape was, from the very beginning, subject to the interpretation and reinvention of visitors.

Thus, to the extent that Iceland has always been exposed to visitors' imagination, at least since the arrival of the Vikings (Magnússon 2010; Oslund 2011), the Víkin's response is to highlight its own constructed reality and make visitors aware of their own agency. Inside the exhibit "From Poverty to Abundance," this is further emphasized through the medium of film. A small sitting area affords visitors the ability to view a 58-min long documentary, Give Us This Day (Sveinsson 1997). Set at the Ósvör fishing outpost in Bolungarvík, the film enriches the exhibit with its portrayal of one day in the life of Iceland's rowboat fishermen. Significantly, the 
documentary's concern with the working, cultural, and religious practices is explicitly set against these practices' inevitable extinction due to global pressures. The film's heroes are unaware that their day will end with a visit from a buyer's agents who will warn the captain that the quality of his salting must improve or his products will not be accepted in the international market. This news of impending changes, and the implied criticism of his skill at commodification as the forces of market bear down on the men's working lives, contrasts with the unquestioning faith the crew has in the captain's skills and in God's assistance (Sveinsson 1997). The documentary, like the exhibit as a whole, serves not only to reenact a historical time, allowing the visitor to become immersed in it, but also to suggest the tidings of coming change.

\section{Social change}

A chief concern of political ecology research is to understand how deeply the exercise of political power in resource and environmental management alters social and ecological relations (Robbins 2004). These dynamics are especially evident in the political-power changes that have occurred in Iceland's fisheries. The dynamics of commons enclosure, privatization, or resource decline have not only economic but also cultural and social consequences that speak to the human and morethan-human geography of fishing as a community practice within space (Benediktsson and Waage 2015; Steinberg and Peters 2015). Hence, with each historic change in governance that brought on a shift in fishing practices, the impact went beyond issues such as labor or employment and instead touched upon social practices, community structures, and even more basic modes of human existence within the coastal space. In modern terms, these social changes are further complicated by the embrace of tourism, which brings on its own inherent duality of landscape. The relations of power between communities and their environments in turn become further complicated (Douglas 2014; Mostafanezhad et al. 2016). The following sections outline how these dynamics, or the perceptions of these dynamics, were suggested to us as visitors.

\section{Sea women: from abundance to poverty?}

Gender is entangled with the changing, collective perceptions of the coastal landscape and yet remains relatively underexamined in both political ecology and maritime cultural heritage analyses. But gender reveals a great deal about how heritage is constructed and the power linkages that political ecology sets out to examine. As Andrea Nightingale reminds us, "[ $\mathrm{t}]$ he meaning and relevance of gender are $[\ldots]$ produced in space and in part constitute that space such that neither can preexist the other" (Nightingale 2006, 166). Reviewing the changing role of women in Icelandic fisheries, therefore, helps illustrate the material, conceptual, and social interactions of power within the coastal landscape.

Historically, women were involved in many aspects of Icelandic fishing, from captaining their own fishing vessels, including open rowboats, to cleaning, salting, and barreling herring during the 20th century Great Herring Adventure, grueling work that nevertheless afforded them some measure of independence (Karlsdóttir 2009; Willson 2014). However, industrialization, and later the adoption of ITQs, re-gendered the Icelandic fisheries into an industry where fewer (about 10 $\%$ in total) women participated (Skaptadóttir 2000; Willson 2014). Fishing communities transformed gradually into ones where women and men were limited to different social and economic responses, with women's participation in the industry increasingly marginalized and rendered invisible (Skaptadóttir 2000; Karlsdóttir 2009; Carothers and Chambers 2012; Willson 2014). In the 1990s and the 2000s, these changes paralleled the dynamics of rising inequality between urban and rural communities, with women in rural communities left with fewer economic and educational opportunities (Karlsdóttir 2009).

We encountered a variety of sites and exhibits that emphasized women's experiences. By far, the most prominent of these was the narrative of the "herring girls" who were important driving forces in the Great Herring Adventure, a prominent theme especially at the Djúpavík herring factory and the Siglufjörður Herring Era Museum in northern Iceland. Women's fisheries experiences were also on display through a specialized exhibit at the Víkin on the occasion of the 100th anniversary of Icelandic women's parliamentary right to vote. Women's contemporary roles were portrayed through stories our tour guide related about women working in Suðureyri's fish processing plant in the Westfjords. A recurring theme was the ability of women to gain personal and financial independence just as the nation of Iceland had through its fisheries. The Víkin museum's special exhibit, Sea Women, for example, wove women's experiences into a wider national narrative of historic and social change:

Other overlapping reasons for the declining numbers of seawomen are: the continuing urbanization of Iceland, with young women no longer growing up around fishing; the increased opportunities for women in rural communities; improved roads that make travel more accessible for them; changing Icelandic notions of success; and the changing role of women. Iceland's 2008 economic crash has also made it much harder for women to find work on boats as these jobs have grown much more competitive both because of higher general unemployment and high sea wages because of an increased fish value (Víkin museum 2016). 
Similarly, the representations of women's labor as part of the Great Herring Adventure at both Djúpavík and Siglufjörður emphasize these experiences' importance for growing individual and rural wealth across Iceland. Salting and barreling herring was a grueling task that earned "the herring girls" independence and respect, while helping to establish the young nation's social and political foundations. The land-to-coast migration associated with working in the twentieth-century herring industry provided social mixing and therefore mortar for Iceland's growing sense of nationhood. Meanwhile, the wealth earned by individual workers, women as well as men, supported the growing wealth of the nation. These are the trajectories, then, that women's experiences signify within the exhibits.

Where these representations become problematic is in relation to the social change described above. Even as tourist attractions emphasize the importance of women's participation in Iceland's fisheries, women's actual participation has dwindled, in dynamics caused by political and economic change but ones likely exacerbated by the tourist industry itself. Ironically, for instance, the Víkin special exhibit is based predominantly on the work of yet another visitor, American anthropologist Margaret E. Willson. ${ }^{1}$ At the same time, the emphasis of these exhibits on women's experiences offers a means of celebrating or even reclaiming women's participation in the fishing industry as an aspect vital to Iceland's historic social change. Ultimately, there is a recognition here that fisheries cut across Iceland's socio-cultural fabric across all levels, from the individual, through the regional, to the national and even the global. Indeed, this is an observation consistent with Cote and Nightingale's analysis on the interdependence of social change with the well-being of socio-ecological systems. Gender, along with considerations of other social and cultural dynamics, helps "situate" the community's ability to adapt to the global environmental and economic pressures it faces (Cote and Nightingale 2012). And resilience, as we will show in the following section, constitutes another important concern for the narratives of change we observed in Iceland.

\section{Community and landscape transformation}

\section{The seafood and heritage trail in Suðureyri}

Many of Iceland's destinations make use of landscape branding in order to appeal specifically to the modern eco-traveler. They emphasize sustainability, shifting the narrative away from collapse and toward ideas of conscientious consumption. One such example is The Fisherman, a tourist company based in the small fishing village Suðureyri in the

\footnotetext{
${ }^{1}$ And the authors of this article were similarly visiting Iceland as academic tourists.
}

Westfjords. Its brochures, available at the tourism office in Isafjörður, near to where the cruise ships disgorge their passengers, speak directly to the "blank page" of a landscape reinvented for the visitor. The advertising material appeals to a romantic notion of Suðureyri as "a small fishing village at the edge of the Arctic Circle," and more importantly as "a destination you feel you've got all to yourself" (The Fisherman 2016). More importantly, this destination is literally consumable, with a "Seafood Trail" that affords an opportunity to see "how the thriving community processes Iceland's finest fish and get a fresh taste of it whilst listening to local stories" (ibid). Here, the amalgamation of consumption, both of food and of "local stories," speaks to the duality of a cultural landscape and a community that is adapting to new circumstances, not only through its modernized and sustainable fishing practices but also through its willingness to communicate its culture to the visitor. In other words, the landscape here is characterized simultaneously by "the beautiful scenery" and by the availability of "the local history and the pure seafood in the Westfjords" (ibid). Visitors are invited almost literally to consume the materiality of the environment along with its cultural and historical constructs: "fish heritage play [s] a large role in the region's culture $[\ldots]$ The strong relation to the ocean is evident wherever you go" (ibid).

In short, The Fisherman tours perform Suðureyri's rural resilience as a construct in the face of the new realities of private fishing rights and a tourism-based economy, a form of alternative seafood marketing (Witter and Stoll 2017). The tour of the Icelandic Saga fish processing plant included on the Suðureyri seafood trail also plays specifically to expectations of sustainability by emphasizing its policy of total utilization of the bodies of the fish. The guide specifies that the plant's freezers and assembly lines are powered by the same geothermal energy that heats the community's swimming pool, while the fish are expertly cut by the female fish cutters under tight conditions of sanitation, before being boxed and shipped to well-informed consumers in Europe and the USA (The Fisherman 2016). A series of large billboards outside The Fisherman's seafood kitchen and gift shop explains in four languages just how sustainable the fishing and fish processing is in Sudureyri while at the same time fully consistent with the maritime heritage of the Westfjords region (see Fig. 3).

If the visitor asks questions during the tour of the processing plant, she may learn that as the owner of three, small-scale, line-fishing vessels, 1500 tons of haddock quota, and 500 tons of cod quota, Icelandic Saga is a survivor, if not a beneficiary, of the neoliberal policies that are presented in a somewhat different light by the exhibits at the Víkin museum in Reykjavík. These are the fisheries rationalization policies that reduced the ranks of women in the livelihood that their foremothers excelled at, policies which led other rural villages with less favorable access to fishing grounds and sources of 
Fig. 3 Sustainable fishing village billboards in four languages, on sustainable seafood trail in Suðureyri, Westfjords. Photo by authors

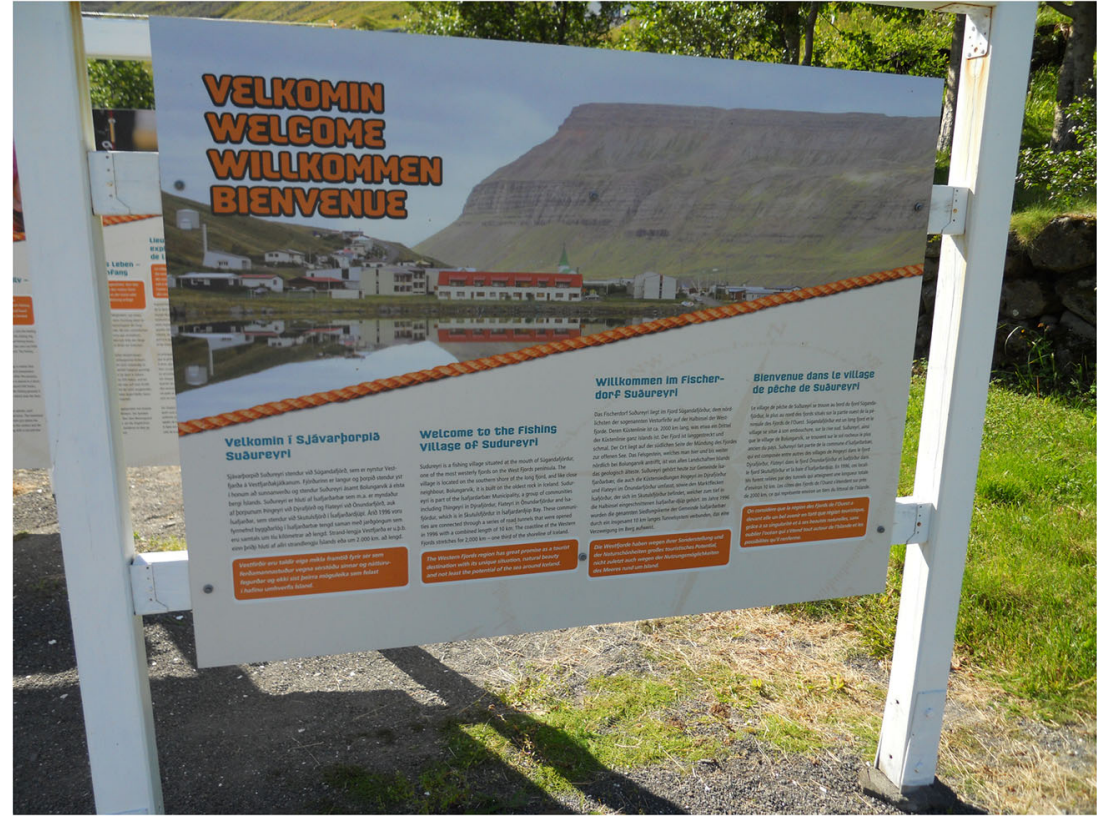

energy to commodify their landscapes and geological wonders for tourism. That the successful outcome of these dynamics here is in turn packaged and sold for consumption is an unintended, problematic message in this narrative. The transformation of a communal and societal value to specifically economic value ultimately enables precisely the kind of alienation from the material landscape that has helped rationalize privatization by fishing quota in Iceland and, on a more global scale, produced what Jason Moore calls "the Capitalocene" (Moore 2017). In this sense, what we might read as performative resilience for the community might equally be seen as a repeated performance of commodification of community value. From a theoretical standpoint, this tension is important. It indicates that the solutions and the problems are entangled on a deep cultural level, one that is hard to disentangle in this context. In the next few sections, this tension comes through in the different representations of industrial heritage from the herring industry, specifically the contrast between two herring factories in the north.

\section{The herring factories}

Two herring factories in northern Iceland, the Herring Era Museum in Siglufjörour and the Djúpavík factory tour, present an alternative means of reclaiming the past for the benefit of tourists. Both destinations draw specifically on the industrial heritage of the Great Herring Adventure, a period spanning the first half of the twentieth century, which helped define and form the nation. During that period, Icelanders joined Norwegian entrepreneurs and industrialists who had discovered great shoals of the surface-feeding AtlantoScandian herring stocks. Northern fjords, geographically close to the herring's summer feeding grounds, attracted men and women from surrounding and distant farming towns to work in the industry, resulting in the establishment of Djúpavík and the growth of Siglufjörour into "The Herring Capital of the World" (Hamilton et al. 2004). The industrial wealth generated by the women and men laboring in the salting stations and reduction factories in these outer fjord towns helped Iceland win political independence from Denmark in 1944. These factories shipped thousands of barrels of salted herring and hundreds of tons of fish meal and fish oil to Europe and North America (Kristfinnsson 2001, cited in Hamilton et al. 2004).

As the name suggests, the Great Herring Adventure is now often presented as a positive experience for the people of Iceland, an assignation with powerful machines, with a modern, global trade, and with the changing oceans. But the era was not an adventure for the herring itself: the transboundary herring stock that supplied this wealth and independence collapsed in the 1960s. A "killer spike" in catches peaking at two million tons, and massive extractions of juvenile fish from spawning grounds in Norway's fjords, collapsed the herring populations (Hamilton et al. 2004, 327; Sigurðsson 2006; Holm 2012). When a fast-moving shift in the Icelandic current made the waters too cold to supply swarms of zooplankton, the herring factories in the north met with rapid decline (Hamilton et al. 2004) (see Fig. 4). It is this collapse, along with the Great Herring Adventure and the consequences from both, that the two herring factory museums in northern Iceland, in Siglufjörour and in Djúpavík, now presents for their visitors. They do so, however, in very distinct ways.

In Siglufjörour, the Herring Era Museum preserves and performs the town's industrial heritage with self-awareness 


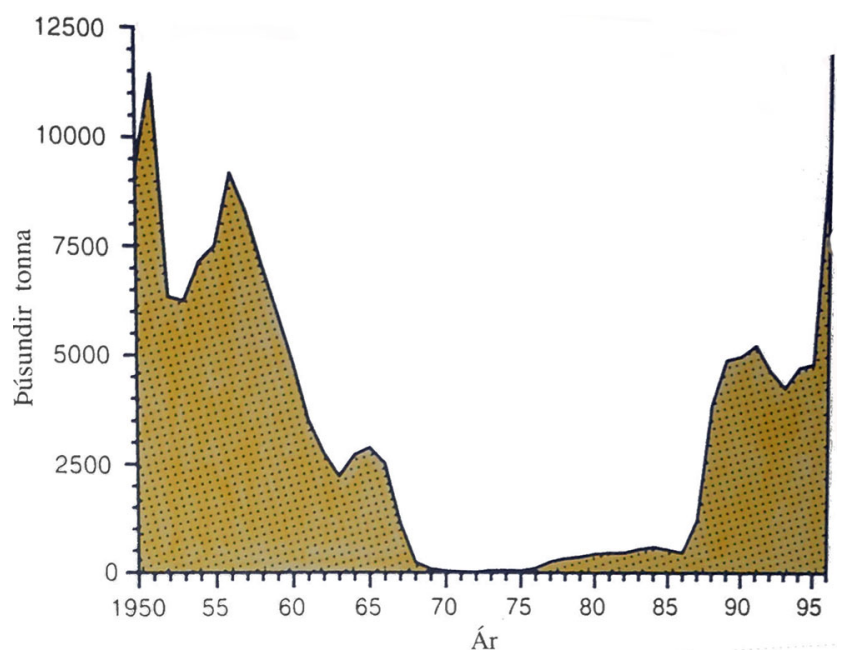

Fig. 4 Graph of herring biomass by thousands of tons showing the "killer spike" in 1965, at the Herring Era Museum, Siglufjörour. Photo by authors

as part of the local and national community's identity. Local citizens contributed their personal expertise, skills, and stories in the course of the museum's construction (Bogan 2004). The museum itself emphasizes the role of volunteers and donations in its material display, its demonstrations, and its explanatory material. For example, it features artwork about the herring industry authored by members of the local community, shows live demonstrations of the herring salting and packaging process presented by town citizens (see Fig. 5), and hosts town meetings and folk gatherings in one of its buildings. In this way, the Herring Era Museum clearly frames its subject in terms of local skills, stories, and sense of place. These aspects, however, are also framed as agents with a national and then global impact. On a national scale, the museum emphasizes discourses of the herring industry as a generational opportunity. A large portion of the exhibit focuses on the daily lives of young adults who came to participate in the industry as a way of earning money and social independence.

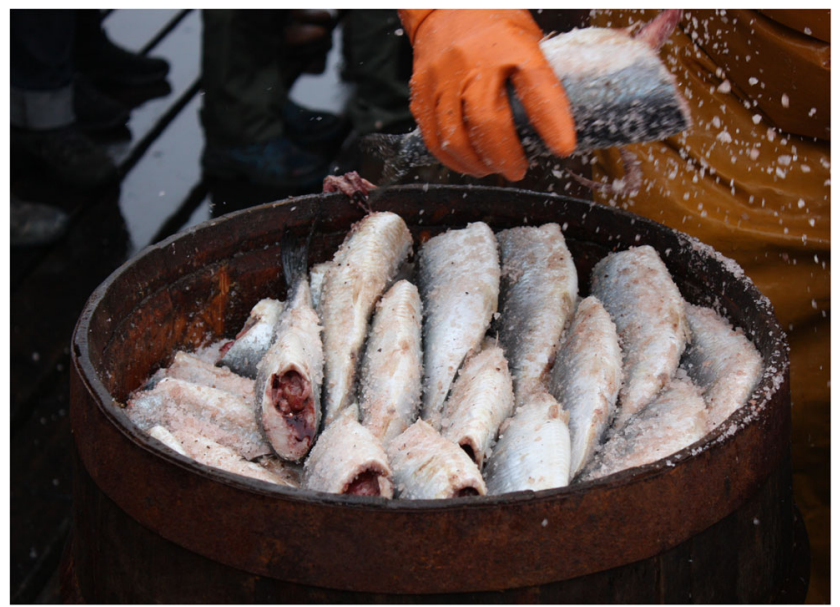

Fig. 5 Salted herring packing demonstration at the Herring Era Museum, Siglufjörður. Photo by authors
It displays, for example, fully furnished dormitory rooms and artifacts of the lives of those young women who came to Siglufjörour to salt herring, thereby escaping more oppressive farm work inland. The Museum's live demonstration likewise forefronts this experience, showing female laborers socializing with each other and noisily flirting with their male counterparts (and bosses) as they work. The industry is presented as "exciting" and "romantic":

The herring towns of Iceland glowed with a vitality and energy not unlike that found in gold rush towns the world over. Wherever communities thrived in the pursuit of the 'silver of the sea', a vigorous brand of excitement filled the air. Even in smaller towns such as Dalvík and Dagverðareyri the feeling was palpable and folks spoke of the romance of the herring (Herring Era Museum 2016)

The museum performs the Great Herring Adventure as a coming of age journey, not only for the individuals who earned financial and personal independence through their employment, but also for the nation as a whole. In the factory manager's office, for example, a 1930s British nautical chart of the fjord and adjacent fishing banks shows the local economy's continued dependence on colonial-style representations of the industrialized marine environment, complete with fishing banks, fouling grounds, and shifting shoals. An entire building is dedicated to the process of distilling fish oil, which, as the plaques clarify, was a geopolitically significant export during WW II as it could be used to make armaments. This product's strategic importance can be divined also by the indoors and out-of-sight location of the processing machines. The Herring Era Museum plays to the contrast, displaying salting and social mixing prominently and audibly outdoors, while keeping the fish oil and fish meal machinery in its original dark, windowless building. Significantly, however, it is in this same building that a stage and a series of benches provide the venue for local town meetings and musical performances. In this way, the Herring Era Museum explicitly links Siglufjörður's local character, presented in the skills, art, and stories of locals, to its national and global impact.

By contrast, the factory tour in Djúpavík focuses not so much on the local community as on the creative representations of the local landscape. Acquired by an Isafjörður native interested in developing tourism (Djúpavík Tour 2016), the abandoned factory romanticizes industrial heritage almost as a relic of human imagination. On display is not only the factory's fish meal processing machinery or its human story but also its decay, its way of standing apart from and blending into the natural landscape, and its many contemporary artistic representations. This sense is first suggested by the factory's very location, which is only reachable by a long, precariously 
winding, potholed gravel road. Once at the factory, visitors must either drive back or stay in the hotel, located within the former women's dormitory. Then, the exhibit inside the factory deliberately utilizes everything that the visitors can seenatural and constructed alike - as a way of evoking their own imaginings. The relationship between the physical and cognitive landscape is emphasized by the tour itself, which explains the vitality of the deep fjord (which provides sea access) and the nearby waterfall (an important electricity generator) to the choice of location for the original herring factory (Djúpavík Tour 2016). Historic and contemporary photographs of the landscape exist side by side with actual views from its windows. Material artifacts from the factory's daily life - a shelf of tin cans, a rotting pickaxe, a dirty canvas bag - are scattered around in an impressionistic, rather than informative, style of display. Moss and mold on the walls punctuate the simultaneous tension and coexistence of industry and nature. Hence, visitors are invited to have an experience that is by turn romantic, post-modern, or post-apocalyptic - in short, a genuine item of Anthropocene tourism. The number of videos of Djúpavík posted on social media attest to the appeal of this invitation (e.g., Heiðdal 2011) (Fig. 6).

The overall impression given from the factory is of a landscape (re)imagined through the creative practices performed by outsiders rather than by locals. These practices include not only the old herring industry itself and the ways in which it appropriated the landscape through its rise and its decline, but also the new industries, tourism, and art, which likewise reinterpret the landscape and its heritage for their own inspiration. The tour spends some time on the story of the 2006 performance of Sigur Rós, a globally known Icelandic band, inside one of the factory's old holding tanks. Famous for drawing its inspiration from the Icelandic landscape, Sigur Rós' choice of venue emphasizes the abandoned factory's character as landscape to be interpreted and (re)created through human industry — whether herring oil, music, or tourism. Indeed,

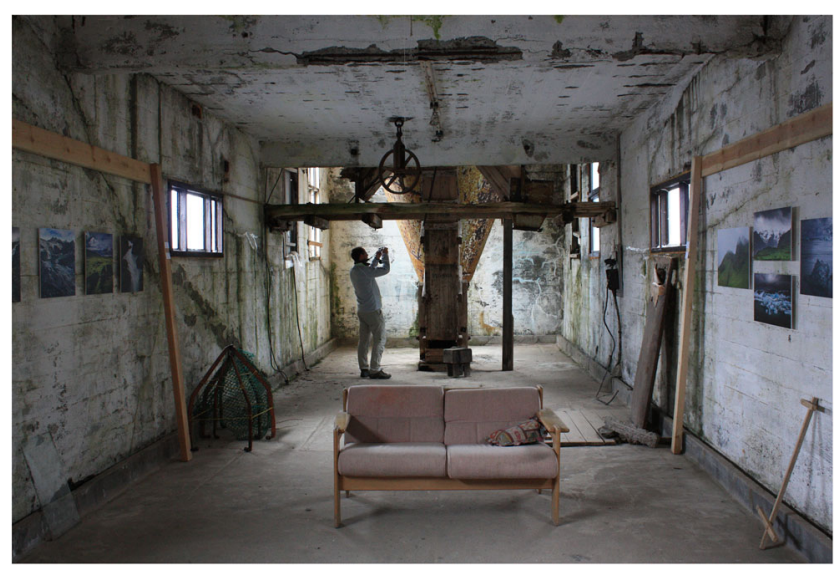

Fig. 6 Soon to be featured? A visitor takes a snapshot in the photography gallery featuring art by past visitors, in the abandoned herring factory at Djúpavík. Photo by authors toward the end of the tour, visitors are invited not only to view the photography exhibit but also to participate in its future editions themselves by submitting their own photos. In this way, tourists themselves-perhaps even the stray researcher-are explicitly prompted to participate in the factory's ongoing reinvention.

\section{Conclusions}

In this "stop-over" visit, our journey has taken us through the history of fisheries and transformations across a range of scales: from a broader national and global perspective presented at Reykjavík's Maritime Museum (Víkin) to regional and local representations of change in the Westfjords and Siglufjörour. What all of these maritime cultural heritage narratives have in common, however, is their willingness to engage beyond their own context. Throughout, the tourist landscape communicated the communities' understanding of their own transformations in a global sense, mindful of issues of connectivity. At the Víkin, as we have demonstrated, fishing was represented as not merely formative to Icelandic national identity but also as a global process of environmental and political change against which this identity was shaped. Similarly, not only the Víkin but also all of the other narratives we encountered displayed an acute awareness of "Iceland imagined" (Oslund 2011) - that is, a sense that the landscapes and history of Iceland were not merely populated but also observed and invented. Hence, even the tourist industry itself could remain cognizant of its own performative aspects. The two different "flavors" of this meta-narrative on display are perhaps best exemplified by the difference between the two herring factories. In Djúpavík, the landscape and heritage are laid out for the reinventing agency of visitors, offering them a transformative experience tailored to their unique taste: a sampling of local culture to resonate on a personal level. In Siglufjörður, by contrast, the landscape and heritage embody a national experience, driven by the energies and agencies of locals, performed to be received rather than appropriated.

Although done in different ways, each of the narratives we encountered charted social change: from the country's formation, through the re-stratification of society as part of the privileging of capital over shared resources, to the shock of drastic shifts in the environment and in economic practices. However, even in detailing the histories of loss, as in the Give Us This Day documentary or in the Siglufjörour Herring Era Museum, these narratives rarely took a romanticized view of the past. Instead, as at Suðureyri, Djúpavík, and Siglufjörður, they offered a means of reimagining the future and enacting resilient practices. As we have seen, however, there are inherent tensions in these representations. They reflect the difficult interplay of power that exists between cultural heritage, the economic and societal aspects of community well-being, and the environment itself. In that sense, it is significant that the 
discourses we examined - discourses that were after all selected for their deliberate performativity - chose to communicate to visitors like ourselves their deep concern with social change. This choice indicates growing awareness of the complexity of these social and environmental challenges, not only in academic settings, but also within the communities themselves.

In future research, we would be curious to reflect on the communicative process itself, and to speak with communities surrounding the display, so as to inquire further into the deliberations that produce such narratives. From this project, however, we would already conclude that the reflexivity ingrained in discourses intended for the visitor's eye raises important questions about social transformations in Iceland's coastal communitiesquestions that we think translate to similar communities elsewhere, as well. A key concern pertains to the tension between these discourses' capacity to convey - that is, to perform - and their desire simultaneously to reflect or preserve. In particular, as tourism continues to grow, maritime cultural heritage sites in Iceland and elsewhere may increasingly face a choice between preserving local community identity or subversive culture on the one hand and appealing to the cultural, economic, and environmental pressures of sustainability-seeking tourists. Thus, political ecology remains a vital lens for examining Icelandic coastal communities' efforts to curate collapse — or catalysis.

Acknowledgments The authors would like to thank Dr. Catherine Chambers and Jennifer Smith at the University Centre of the Westfjords for their help identifying research sites in northern Iceland, as well as the wider community of scholars at the MARE 2015 and 2017 conferences in Amsterdam.

Funding information The authors would like to acknowledge that this project has received funding from the European Union's Horizon 2020 research and innovation programme under the Marie Skłodowska-Curie ITN ENHANCE (grant agreement no. 642935).

\section{Compliance with ethical standards}

Conflict of interest The authors declare that they have no conflict of interest.

Publisher's Note Springer Nature remains neutral with regard to jurisdictional claims in published maps and institutional affiliations.

Open Access This article is distributed under the terms of the Creative Commons Attribution 4.0 International License (http:// creativecommons.org/licenses/by/4.0/), which permits unrestricted use, distribution, and reproduction in any medium, provided you give appropriate credit to the original author(s) and the source, provide a link to the Creative Commons license, and indicate if changes were made.

\section{References}

Baum, Tom. 1999. The decline of the traditional North Atlantic Fisheries and Tourism's Response: the cases of Iceland and Newfoundland. Current Issues in Tourism 2: 47-67. https://doi.org/10.1080/ 13683509908667843.
Benediktsson, Karl. 2014. Nature in the "neoliberal laboratory.". Dialogues in Human Geography 4: 141-146. https://doi.org/10. 1177/2043820614536340.

Benediktsson, Karl, and Anna Karlsdóttir. 2011. Iceland: crisis and regional development - thanks for all the fish? European Urban and Regional Studies 18: 228-235. https://doi.org/10.1177/ 0969776411402282.

Benediktsson, Karl, and Edda R.H. Waage. 2015. Taskscapes at sea: Trawler fishing and the experience of fluid nature. Environment, Space, Place 7 (2): 41-64.

Bogan, Chris. 2004. Grinding away the rust: the legacy of Iceland's herring oil and meal factories. Gastronomica 4: 51-57.

Bonehill, John. 2014. "New scenes drawn by the pencil of truth": Joseph Banks' northern voyage. Journal of Historical Geography 43: 9-27. https://doi.org/10.1016/j.jhg.2012.05.018.

Carothers, Courtney, and Catherine Chambers. 2012. Fisheries privatization and the remaking of fishery systems. Environment and Society: Advances in Research 3: 39-59. https://doi.org/10.3167/ares.2012.030104.

Chambers, Catherine, and Courtney Carothers. 2017. Thirty years after privatization: A survey of Icelandic small-boat fishermen. Marine Policy 80: 69-80. https://doi.org/10.1016/j.marpol.2016.02.026.

Chambers, Catherine, Guðrún Helgadóttir, and Courtney Carothers. 2017. "Little kings": community, change and conflict in Icelandic fisheries. Maritime Studies 16: 10. https://doi.org/10.1186/s40152017-0064-6.

Cote, Muriel, and Andrea J. Nightingale. 2012. Resilience thinking meets social theory: Situating social change in socio-ecological systems (SES) research. Progress in Human Geography 36: 475-489. https://doi.org/10.1177/0309132511425708.

Djúpavík Tour. 2016. Factory art exhibit. Djúpavík, Westfjords.

Douglas, Jason A. 2014. What's political ecology got to do with tourism? Tourism Geographies 16: 8-13. https://doi.org/10.1080/14616688. 2013.864324.

Durán, Roi, Begoña A. Farizo, and María Xosé Rodríguez. 2015. Conservation of maritime cultural heritage: a discrete choice experiment in a European Atlantic region. Marine Policy 51: 356-365. https://doi.org/10.1016/j.marpol.2014.09.023.

Einarsson, Niels. 2011. Fisheries governance and social discourse in postcrisis Iceland: responses to the UN Human Rights Committee's Views in Case 1306/2004. The Yearbook of Polar Law 3: 479-515.

Eythórsson, Einar. 2000. A decade of ITQ-management in Icelandic fisheries: consolidation without consensus. Marine Policy 24: 483-492. https://doi.org/10.1016/S0308-597X(00)00021-X.

Eythórsson, Einar. 2003. Stakeholders, courts, and communities: individual transferable quotas in Icelandic fisheries, 1991-2001. In The commons in the new millennium: challenges and adaptations, ed. Nives Dolšak and Elinor Ostrom, 129-167. Cambridge: MIT Press.

Flyvbjerg, Bent. 2011. Case study. In The Sage Handbook of Qualitative Research, ed. Norman K. Denzin and Yvonna S. Lincoln, 4th ed., 301-316. Los Angeles: Sage.

Gill, Alec. 2003. Hull's fishing heritage: aspects of life in the Hessle Road fishing community. Barnsley: Wharncliffe Books.

Glaser, Barney G., and Anselm L. Strauss. 1967. The discovery of grounded theory: strategies for qualitative research. New York: Aldine de Gruyter.

Gopnik, Adam. 2016. Iceland's Historic Candidate. The New Yorker, July $11 \& 18$.

Guðmundsson, Guðmundur J. 2006. The Cod and the cold war. Scandinavian Journal of History 31: 97-118. https://doi.org/10. 1080/03468750600604184.

Hamilton, Lawrence C., Steingrímur Jónsson, Helga Ögmundardóttir, and Igor M. Belkin. 2004. Sea changes ashore: the ocean and Iceland's herring capital. Arctic 57: 325-335.

Heiðdal, Hjalmtyr. 2011. The herring made us all rich. Vimeo, Oct. 27, 2011.

Holm, Poul. 2012. World war II and the "great acceleration" of North Atlantic fisheries. Global Environment 5: 66-91. 
Holm, Petter, Jesper Raakjær, Rikke Becker Jacobsen, and Edgar Henriksen. 2015. Contesting the social contracts underpinning fisheries-lessons from Norway, Iceland and Greenland. Marine Policy 55: 64-72. https://doi.org/10.1016/j.marpol.2015.01.011.

Huijbens, Edward H., and Karl Benediktsson. 2013. Inspiring the visitor? Landscapes and horizons of hospitality. Tourist Studies 13: 189208. https://doi.org/10.1177/1468797613490378.

Jensen, John Odin, Roderick Mather, and Jeff Gray. 2011. Viewing the future through the lens of maritime cultural landscapes. Sanctuary Watch: 2-3.

Jóhannesson, Guðni Thorlacius. 2004. How "Cod war" came: the origins of the Anglo-Icelandic fisheries dispute, 1958-61. Historical Research 77: 543-574. https://doi.org/10.1111/j.1468-2281.2004.00222.x.

Jóhannesson, Guðni Thorlacius. 2016. The past, present and future of wild Iceland. Leeds, United Kingdom.

Jóhannesson, Gunnar Thór, and Edward H. Huijbens. 2010. Tourism in times of crisis: exploring the discourse of tourism development in Iceland. Current Issues in Tourism 13: 419-434. https://doi.org/10. 1080/13683500.2010.491897.

Jóhannesson, Gunnar Thór, Edward Hákon Huijbens, and Richard Sharpley. 2010. Icelandic tourism: past directions-future challenges. Tourism Geographies 12: 278-301. https://doi.org/10. 1080/14616680903493670.

Karlsdóttir, Anna. 2009. Are living fish better than dead fillets? The invisibility and power of Icelandic women in aquaculture and the fishery economy. In Gender, Culture and Northern Fisheries, ed. Joanna Kafarowski, 67-84. Edmonton: CCI Press. https://doi.org/ 10.1017/CBO9781107415324.004.

Kokorsch, Matthias, and Karl Benediktsson. 2018. Prosper or perish? The development of Icelandic fishing villages after the privatisation of fishing rights. Maritime Studies 17: 1-15. https://doi.org/10.1007/ s40152-018-0089-5.

Kokorsch, Matthias, Anna Karlsdóttir, and Karl Benediktsson. 2015. Improving or overturning the ITQ system? Views of stakeholders in Icelandic fisheries. Maritime Studies 14: 15. https://doi.org/10. 1186/s40152-015-0033-x.

Li, Tania Murray. 1996. Images of community: discourse and strategy in property relations. Development and Change 27: 501-527. https:// doi.org/10.1111/j.1467-7660.1996.tb00601.x.

Magnússon, Sigurður Gylfi. 2010. Wasteland with words: a social history of Iceland. London: Reaktion Books.

Moore, Jason W. 2017. The Capitalocene, part I: on the nature and origins of our ecological crisis. Journal of Peasant Studies 44: 594-630. https://doi.org/10.1080/03066150.2016.1235036.

Mostafanezhad, Mary, Roger Norum, Eric J. Shelton, and Anna Thompson-Carr. 2016. Introduction. In Political ecology of tourism: community, power, and the environment, ed. Mary Mostafanezhad, Roger Norum, Eric J. Shelton, and Anna Thompson-Carr, 1-22. New York: Routledge.

Nadel-Klein, Jane. 2003. Fisherfolk under glass? Memory and the heritage wars. In Fishing for heritage: Modernity and loss along the Scottish coast, 171-212. Oxford: Berg Publishers.

Nightingale, Andrea. 2006. The nature of gender: work, gender, and environment. Environment and Planning D: Society and Space 24: 165-185. https://doi.org/10.1068/d01k.

Óladóttir, Oddný Póra. 2016. Tourism in Iceland in Figures.

Olwig, Kenneth R. 2005. Representation and alienation in the political landscape. Cultural Geographies 12: 19-40. https://doi.org/10. 1191/1474474005eu321oa.

Oslund, Karen. 2011. Iceland imagined: nature, culture, and storytelling in the North Atlantic. Seattle: University of Washington Press.
Ounanian, Kristen. 2018. Not a 'museum town': discussions of authenticity in coastal Denmark. Journal of Tourism and Cultural Change: 16: 1-16:21. https://doi.org/10.1080/14766825.2018.1456544.

Peet, Richard, and Michael Watts, eds. 2004. Liberation ecologies: environment, development, social movements. 2nd ed. London: Routledge.

Pitcher, Tony J., and Mimi E. Lam. 2015. Fish commoditization and the historical origins of catching fish for profit. Maritime Studies 14: 2. https://doi.org/10.1186/s40152-014-0014-5.

Robbins, Paul. 2004. Political ecology: a critical introduction. 2nd ed. Chichester: Wiley-Blackwell.

Sampaio, Sofia, Valerio Simoni, and Cyril Isnart. 2014. Tourism and transformation: negotiating metaphors, experiencing change. Journal of Tourism and Cultural Change 12: 93-101. https://doi. org/10.1080/14766825.2014.924674.

Sigurðsson, Thorir. 2006. The collapse of the Atlanto-Scandian Herring Fishery: the effects on the Icelandic economy. In IIFET 2006 Proceedings, 1-9. UK: Portsmouth.

Skaptadóttir, Unnur Dís. 2000. Women coping with change in an Icelandic fishing community: a case study. Women's Studies International Forum 23: 311-321. https://doi.org/10.1016/S02775395(00)00089-3.

Smith, Melanie K. 2003. Issues in cultural tourism studies. London and New York: Routledge.

St. Martin, Kevin. 2009. Toward a cartography of the commons: constituting the political and economic possibilities of place. The Professional Geographer 61: 493-507. https://doi.org/10.1080/ 00330120903143482.

Steinberg, Philip, and Kimberley Peters. 2015. Wet ontologies, fluid spaces: giving depth to volume through oceanic thinking. Environment and Planning D: Society and Space 33: 247-264. https://doi.org/10.1068/d14148p.

Sveinsson, Erlendur. 1997. Give us this day. Iceland: Icelandic Film Fund.

The Economist. 2016. It's not up to you; Iceland's post-crisis economy. The Economist 421: 75.

The Fisherman. 2016. Suðureyri, Westfjords.

Tsing, Anna Lowenhaupt. 2005. Friction: an ethnography of global connections. Princeton: Princeton University Press. https://doi.org/ 10.1017/S0010417505220297.

Tuddenham, David Berg. 2010. Maritime cultural landscapes, maritimity and quasi objects. Journal of Maritime Archaeology 5: 5-16. https:// doi.org/10.1007/s11457-010-9055-0.

UNWTO. 2016. UNWTO tourism highlights, 2016 edition. https://doi. org/10.18111/9789284418145.

Vikín (Reykjavík Maritime Museum). 2016. Main and temporary exhibits. Reykjavík

Westerdahl, Christer. 1992. The maritime cultural landscape. The International Journal of Nautical Archaeology 21: 5-14.

Willson, Margaret Elizabeth. 2014. Icelandic fisher women's experience: implications, social change, and fisheries policy. Ethnos: Journal of Anthropology 79: 525-550. https://doi.org/10.1080/00141844. 2013.783606.

Witter, Allison, and Joshua Stoll. 2017. Participation and resistance: alternative seafood marketing in a neoliberal era. Marine Policy 80: 130-140. https://doi.org/10.1016/j.marpol.2016.09.023.

Web pages cited

The Herring Era Museum. 2016. http://www.sild.is/en. Last accessed 09 May 2018. 